\title{
COGNITIVE SIGNIFICANCE OF SEMANTIC CHANGES (ON THE EXAMPLE OF LEXICAL UNITS IN UZBEK AND ENGLISH)
}

\author{
Muxtorjon Yakubovich Baxtiyarov \\ Doctor Of Philology (Phd) Uzbekistan State World Languages University
}

\section{ABSTRACT}

The aim of this article is to describe the cognitive and lexico-semantic features of semantic displacement in Uzbek and English with the examples of lexical units in both languages. As a source for comparison there were chosen the examples from lexical units which are mainly used in everyday life of both nations. While comparing the given material the main attention was paid to the chosen lexemes.

KEYWORDS: - Semantic displacement, deduction, widening of the meaning, narrowing of the meaning, individual, semantic parallelism, antroponic analyze, frame, nominative, cognitive meaning.

\section{INTRODUCTION}

The phenomenon of semantic privatization is an active process in the development of modern Uzbek and English languages at the level of language standards. The narrowing of meaning is a semantic parallel in language of deduction, which is one of the main tendencies of thinking, and it represents the movement of thought from semantic uncertainty to spiritual clarity.

Semantic shifts are mainly the result of rethinking, which includes phenomena such as meaning widening (generalization), meaning narrowing (privatization), and displacement of meaning.

This phenomenon of change in meaning is based on various logical and psychological processes, but because rethinking occurs in a single area of understanding, we can see semantic shifts in the following three phenomena:

1. Expanding meaning is generalization.

2. Narrowing the meaning - privatization.

3. Shift is a "shift" in the meanings of a word.

The terms "widening" and "narrowing" are traditional and well known to linguists. A characteristic feature of these terms is that they simultaneously represent the result of a process of rethinking. Based on anthroponomic analysis, we can observe many examples demonstrating the phenomenon of expansion of meaning.

For example, the Uzbek lexeme "Yaylov (pasture)" originally meant "spending summer on the grass on the top of a mountain"; in the ancient Turkic 
CURRENT RESEARCH JOURNAL OF PHILOLOGICAL SCIENCES 2(11):

44-47, November 2021

DOI: https://doi.org/10.37547/philological-crjps-02-11-11

ISSN 2767-3758

(C2021 Master Journals

Crossref do

gil Google

Accepted $25^{\text {th }}$ November, 2021 \& Published $30^{\text {th }}$ November, 2021

language, the lexeme "Yay" meant "summer", and the lexeme "Yaylov (pasture)" - "the place where people spent summer" [1].

During the summer, the herdsmen grazed their cattle in the "yaylaqlar (pastures)" at the top of the mountain, and in the winter they moved from the "yaylaq (pasture)" to the "qishlaq (village)". Nowadays, the lexeme of yaylag (pasture) means not only "a pasture where cattle graze on the top of a mountain", but also "any large area where cattle graze, a pasture".

Such a meadow can be found at the top of a mountain, in the steppes and even in the low plains. This expansion of the meaning also occurred in the context of the village lexeme: it originally meant "a place to live in the winter" ("the grazing of livestock on wintering land"), but now it means "a point where the population is mostly engaged in agriculture."

Although both the "qishloq (village)" and "yaylov (pasture)" lexemes are derived words in the diachronic aspect, in the synchronous aspect they are the root word.

In linguistics, it is also observed that the transformation of proper nouns into appellative nouns is also considered an extension of meaning. For example, Roentgen (proper name), Roentgen (X-ray) (name of equipment), Rizamat (proper name), rizamat (local, grape variety) [2].

Expansion of meaning is a semantic parallel of induction in language - a process of thinking, that is, the expansion of meaning "shifts" from to uncertainty, and in the narrowing - from uncertainty to clarity. In a word, personal facts refer to the movement of knowledge based on a general rule of knowledge previously acquired by the speaker.
In English linguistics, the phenomenon of semantic expansion is also observed. For example, the word pioneer, which came from the French during the initial formation of English, was originally used in the army [3]. That meant a soldier who cleared the way for the soldiers going after them, cut down trees, did all sorts of dirty work, and had the lowest army rank. In the seventeenth century, as a result of the expansion of the original meaning, a new meaning of "leading the way, exploring new territories" emerged.

Similar cases can also be found in the expansion of word meanings, which are clearly reinforced in the concept of collective language in the concept and its categorical features.

Simply put, we can observe the expansion of meaning even more often in familiar social spheres. In England, for example, the term merchant was used to refer to men who held important positions, their voices played an important role in public administration. Today, the term "savdogar (merchant)" is actively used in Uzbek linguistics. But the term is now being applied to men and women who have lost their main meaning and are engaged in trade.

A lexeme that is experiencing a narrowing of meaning may be the only linguistic fact that has developed from the general rules in the brain of the speaker and the listener and is common to the speakers in the community. By process of meaning narrowing, we mean the narrowing of the volume of a word signification, i.e., if at the beginning of a word it means the name of an entire category, as a result of meaning widening and narrowing, that item represents the name of one of its directions or types. For example, the word fowl in English means "bird" in Old English and 'a born-door fowl, a domestic cock or hen' in modern English [8]. 
CURRENT RESEARCH JOURNAL OF PHILOLOGICAL SCIENCES 2(11):

44-47, November 2021

DOI: https://doi.org/10.37547/philological-crjps-02-11-11

ISSN 2767-3758

(C2021 Master Journals

Crossref do

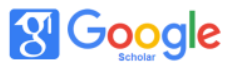

Accepted $25^{\text {th }}$ November, 2021 \& Published $30^{\text {th }}$ November, 2021

In most cases, the development of the semantic essence of a single word can be an example of both narrowing and widening of meaning. There are such lexemes, though infrequently, in Uzbek and English.

For example, "Vatan (country)" (in the narrow sense - "the city or village where a person was born and raised"), "Vatan (country)" (in the broadest sense - "the country where a person was born and raised").

We face similar words in English lexicology as well. For example, in the early days of medieval English, the word president was originally used as a military term: colony, applied to division leaders. Later, the head of finance, the head of the company, and finally privatized (narrowing the meaning) is used in the sense of "head of the republic." Today's semaphores of "head of the company, head of finance" are "extinct", that is, they have lost their meaning and do not resonate at the level of the head of state.

In the linguistic literature, semantic expansion has been highlighted as a less common semantic process than semantic narrowing [7].

Narrowing is less commonly used in the thought process than widening in terms of cognition because it is based on deduction, which is much simpler in a logical mechanism compared to induction.

The broader and more ambiguous the meaning of a given word, the narrower its meaning obtained as a result of narrowing.

It is not uncommon for us to see an expansion of meaning even in the process of transforming a word from a professional jargon into a commonly used word. For example, the word junk was originally a slang word meaning "old rope" for sailors, and later, by the end of the 19th century, it became widely used among people to mean "something no one needs, rubbish cloth". This trend is cited by A. Meye in his work [5].

Any socio-professional group can turn word semantics into a polysemous word in their nominative and communicative needs. Because, as mentioned above, the word has to evoke a desire for the needs of cognition as a result of the transition from a general meaning to a specific meaning, and requires a broader cognitive knowledge.

A shift in the meaning of a word is a "shift" that occurs in the status of the meaning of the word.

Changing the status of variants in the lexical sense of a word is based on induction and deduction, as does the narrowing and expansion of meaning. However, when the parametric status of a lexical meaning of a word is changed, in addition to the logical mechanism, an associative mechanism is activated that brings the realization of statutive parameterization closer to the metaphor.

The action of the associative process leads to the emergence of connotative components in the semantic structure of the word, and their relevance expresses the explicit idea.

For example, in all ages, people were well aware of the role that butchers did. The word butcher (qassob), has survived to the present day in the early English period as 'one whose trade it is to slaughter large tame animals for food: one who kills such animals and sells their fresh'. As a result of the shift, in the Middle Ages of English there appeared a new meaning word 'an executioner', and in the early period of the new English language there appeared a new meaning 'a man of blood, a brutal murder' [6]. 
CURRENT RESEARCH JOURNAL OF PHILOLOGICAL SCIENCES 2(11):

44-47, November 2021

DOI: https://doi.org/10.37547/philological-crjps-02-11-11

ISSN 2767-3758

(C)2021 Master Journals

crossref do) 8: Google

Accepted25 $5^{\text {th }}$ November, 2021 \& Published 30th November, 2021

There are such words in the Uzbek language that have the same shift meaning. For example, the lexeme farmer.

The Turkic peoples were a sedentary people. They were considered the owners of the land-water. They were engaged in agriculture and animal husbandry. Therefore, the lexeme dehqon (tiller) was used in ancient times to mean "self-sufficient, landowner."

At certain times, it was replaced by the lexeme "dehqon (tiller)" and regained its original meaning. Similar words in the Uzbek language are an example of semantic shift.

In conclusion, it can be said that the shifts in the meaning of the word indicate the high level of realization in the associative network of the cultural-linguistic society, which forms the basis of its definition.

The linguistic means of semantic shift is the consolidation of cognition and knowledge in the cognitive system.

At the heart of semantic shift, in the act of semantic derivation, there are the frames that carry out and systematize the process of cognitive processing of information.

\section{REFERENCES}

1. Jamolxonov H. Hozirgi o'zbek adabiy tili. - T.: "O'zbekiston milliy ensiklopediyasi", 2013. B. 269.

2. Rahmatullaev Sh. O'zbek tilining etimologik lig'ati. Turkey so'zlar. - T.: Universitet, 2000. - B. 126.

3. Kubryakova E.S. Yazik I znachenie. Na puti polucheniya znaniy o yazike: chsti rechi s kognitivnoy tochki zreniya. Rol yazika $\mathrm{v}$ poznanii mira. - Moskva: Progress, 2004. 512 str.

4. Gak V.G. Yazikovaya preobrazovaniya. Moskva: Nauka, 1998. - 586 str.

5. Meillet A. Linguistique historique et lingistique general. Paris,1926. Metaphor: problems and perspectives / Ed. D. Mial. Brighton, 1982. Metaphor and thought / Ed. A. Ortony. Cambridge, 1988.

6. Ullman S. Semantics: an introduction to the science of meaning. Oxford, 1962, p. 229.

7. Williams J.M. Origins of the English Language: A Social and Linguistic History. N.Y. 1975. p. 177.

8. Oxford Dictionary and Thesaurus. - Oxford University Press. 1995. 